\title{
A NEI' SPECIES OF IEPTOSPHAERIA CAUSING LEAF \\ BLIGHT OF COMMON GARDEN ASPARAGUS \\ IN PUERTO RICO
}

Some years ago a severe leaf blight was found in a field of common vegetable asparagus, Asparagus officinalis $\mathrm{L}$. var. altilis $\mathrm{L}$., growing as an experiment near Bayamón. A close examination was made of the leaf spots and they were found to be caused by a Leptosphaeria. The trouble resulted in much defoliation that severely damaged the plants. Indeed, this disease may have been a potent factor in hindering the development of asparagus as a crop in the Island of Puerto Rico. Studies were made and it was found that the malady could be controlled by careful, periodic sprayings with Bordeaux mixture of the $3: 3: 50$ formula.

A description of this leaf blight organism is herewith presented: Leptosphaeria portoricensis n. sp. Perithecia sparce vel gregaria, in stromatibus tenuissimo-elongatis, apheriodes vel sphaeriodes-applanatis, nigro-brunneis, ostiolis erumpentibus, rigidis, erectis, mamiliformis demun 80 to $160 \mu$ : elongatis, cylindricis-clavatis, paraphysatis, subsesilibus 60 to $75 \times 6-9 \mu$; octosporis, sporidias curvatis fusiformibus, 3-scptates, profunda constrictus ad septa, locule inferiori hyalinis, accuminate, $1 ;-17 \times 3-4 \mu$, fuligeneis, loculi superiori crassiori, globosis.

Luis A. Alrarez García

Department of Phytopathology and Botan!! 